\title{
THE NUMERICAL RESEARCH OF THE FLOW IN THE INLET OF THE HIGH- HEAD HYDRAULIC TURBINE
}

\author{
K. REZVAYA*, E. KRUPA, V. DRANKOVSKIY, O. POTETENKO, I. TYUNYANOVA
}

\author{
Department of Hydraulic machines, National Technical University "Kharkov Polytechnic Institute", Kharkov, UKRAINE \\ *email:rezvayaks@gmail.com.
}

\begin{abstract}
D-methods for the calculation of flow are used in this work. The solid model of the inlet is created. The mesh of the tetrahedral type is constructed. The boundary conditions for the calculations in the program are given, namely: the rate in inlet of the spiral casing and pressure on an exit. The choice of the turbulence model was based on the tasks that were set earlier. The results of numerical research of three-dimensional flow of a fluid flow in the high-head radial-axial hydraulic turbine are presented. Calculations are conducted for prognostication of descriptions and optimization of form of water passage of hydraulic turbines. The calculation of coefficient of losses of kinetic energy in the elements of inlet of hydraulic turbine is conducted. The total energy losses in the inlet of the water passage using different applied program packages are determined. The comparison of the data, which was obtained by in the calculations and the experimental data, is produced. The distributions of the total pressure and static pressure are presented in this paper. The velocity distribution in the meridional sections is presented. The complex nature of fluid flow is described. The secondary fluid flow in the spiral casing of the hydraulic turbine is confirmed by calculations. This secondary motion in the spiral casing of the hydraulic turbine appears due to the complexity of the fluid flow. Conclusions about the results of the three-dimensional calculations are made. Using special programs in the design of hydraulic turbines can reduce the technological resources and time.
\end{abstract}

Keywords: hydraulic turbine; inlet; $k$ - $\varepsilon$ model of turbulence; coefficient of losses; distribution of pressure; distribution of velocity; secondary motion

\section{ЧИСЕЛЬНЕ ДОСЛІДЖЕННЯ ПОТОКУ В ПІДВОДІ ВИСОКОНАПІРНОЇ ГІДРОТУРБІНИ}

\section{К. С. РЕЗВА, С. С. КРУПА, В. Е. ДРАНКОВСЬКИЙ, О. В. ПОТЕТЕНКО, І. І. ТИНЬЯНОВА}

Кафедра «Гідравлічних машин», Національний технічний університет «Харківський політехнічний інститут», Харків, УКРАЇHA

АНОТАЦІЯ Представлені результати чисельного дослідження тривимірної течї потоку рідини в високонапірній радіально-осьовій гідравлічній турбіні. Визначено втрати повної енергї в підвідних елементах проточної частини за допомогою різних пакетів прикладних програм. Проведено порівняння даних, отриманих при розрахунках та експериментальних стендових даних. Описано складний характер течї потоку рідини. Розрахунковим иляхом підтверджено наявність вторинний рух рідини в спіральній камері гідравлічної турбіни. Порівняно результати, які отримані шляхом розрахунку із застосуванням пакетів програм а також експериментальні данні.

Ключові слова: гідравлічна турбіна; підвідна частина; $k$-є модель турбулентності; коефіцієнт втрат; розподіл тиску; розподіл ивидкості; вторинний рух.

\section{Introduction}

Research of losses in water passage is one of basic problems of theory of hydromachines. These calculations on different operating modes allow to define the change of energy of liquid in the different elements of water passage of hydromachines and to investigate process of the forming of optimal mode. All of that allows to get recommendations on the improvement of geometry, both separate elements of water passage and its on the whole [1].

Numeral value of losses determined on the basic of theory of similarity on the non-dimensional coefficients of resistance of $k_{h}$ [2]. It is necessary to know the change of complete pressure in the characteristic sections of running part of hydromachine.

The losses of energy in a hydroturbine consist of hydraulic, mechanical, and volumetric. Disk and hydraulic losses make the basic part of losses in a highhead hydroturbine. They differentiate at the place of origin (in a spiral casing, stator, wicket gate, runner and draft tube).

For the high-head hydroturbines losses of energy in inlet equal to the half of all hydraulic losses in water passage. Therefore, it is necessary to give large attention during designing of the inlet of high-head hydromachine [3].

For perfection of water passage of hydraulic machine with high power indexes it is necessary to choose all elements on kinematics parameters, taking into account the difficult picture of three-dimensional fluid flow in them.

Nowadays there is a variety of the programs for a calculation and analysis of the fluid flow in hydraulic machines. They got a wide use. The numeral design of three-dimensional turbulent flow of liquid is realized in 
these programs (Fluent, CFX, OpenFoam, Flow Vision, Numera). They allow to get the detailed information about character of flow and to determine average value of kinematics characteristics in the specified sections of water passage

\section{The aim of the paper}

Comparison and analysis of data, which have been got by different calculation programs, and experimental data is the aim of this work.

\section{Exposition of basic material}

Calculations of three-dimensional turbulent flow of liquid in the inlet were carried out in this work. They were compared with the results of experimental data, and calculations on the basic of direct problem of CCTI.

High-head Francis turbine Fr500-B-100 with head $500 \mathrm{~m}$ have been considered. The inlet of hydro-turbine consisted of spiral casing (SC), columns of stator and wicket gate (WG). A spiral casing has circular and elliptical meridian cross-sections, the angle of coverage in the plan $\varphi=360^{\circ}$, the coefficient of velocity in the inlet section $K=0.755$. A spiral casing is expected by law of constancy of moment of velocity $\left(V_{u} \cdot r=\right.$ const $)$. There are 12 vanes in stator. The number of vanes of wicket gate is equal to 24 , the profile them has positive curvature.

Three operating modes with the reduced rates and opening of wicket gate were considered (reduced values for the diameter of model $\left.D_{l}=400 \mathrm{~mm}\right)$ :

1 mode: $Q_{I}{ }^{\prime}=0.225 \mathrm{~m}^{3} / \mathrm{s}, a_{0}=19 \mathrm{~mm}$;

2 mode: $Q_{I}{ }^{\prime}=0.250 \mathrm{~m}^{3} / \mathrm{c}, a_{0}=22 \mathrm{~mm}$;

3 mode: $Q_{I}{ }^{\prime}=0.270 \mathrm{~m}^{3} / \mathrm{c}, a_{0}=24 \mathrm{~mm}$.

Experimental researches were conducted on the installation of department of hydraulic machines for the hydroturbine of Fr500 with different modifications of water passage [4]. The variant of inlet for comparison with numeral researches of fluid flow was chosen. These calculations were produced in the package of softwares of CFD.

Boundary conditions were set for a calculation in the program, namely: the rate in inlet of the spiral casing and pressure on an exit. All calculations were conducted for the diameter of runner, which equal $1 \mathrm{~m}$, and for the head $H=1 \mathrm{~m}$, the $k-\varepsilon$ model of turbulence of flow was chosen.

It is a simple two-parameter model of turbulence. Two equations of transfer are calculated in this model, they determine turbulent velocity and length scale. It traditionally is considered that the standard $k-\varepsilon$ model of turbulence provides good results at the design of fluid flows with small gradients and with the using of the calculation mesh (with the large values of parameter of $\left.\mathrm{y}^{+}\right)$. Therefore, it be possible to say, that the $k$ - $\varepsilon$ model is very popular due to rapid convergence and relatively low requirements to the volume of memory during the solving of the applied hydrodynamic problems.

The value of relative kinematics energy of turbulence of the fluid flow was set for every calculating mode. It depends of parameters of the fluid. In this paper $k$ was accepted $5 \%$ from the possible range of values that can choose automatically in the program $(1 \%, 5 \%, 10 \%)$. Also for the existent complexes of the programs, it is possible by hand to set parameters. Then calculate every parameters by formulas and vary initial data.

\section{Discussion of results}

Comparison of calculation and experimental data will allow in the future to simplify the process of modernisation of hydraulic machine during purposeful modifications. In this case, time and resources diminish.

On the first stage of realization of numerical research of the solid model was created (fig. 1), after that the construction of calculation mesh was made (fig. 2). In this work in explored spiral casing with the columns of stator and wicket gate the calculating mesh was built with the total number of cells 4,49 million; 4,64 million; 4,45 million (for every mode accordingly).

Due to complex geometry and difficulty of construction of the block-structured meshes, a tetrahedral mesh was built for the economy of time. There are prismatic layers in wall areas and frontier layer for quality description of processes (for $k-\varepsilon$ choose 12 layers). The thickness of the first wall layer was selected for the providing of the acceptable value of dimensionless value $\mathrm{y}^{+}$. The model of turbulence, which was chosen before, effects on it too (for $k-\varepsilon$ models of turbulence $\mathrm{y}^{+} \leq 100$ ). There is condensing of the mesh near inlet and outlet edges of stator columns and vanes of wicket gate [7-12].

Calculations for three fixed opening of wicket gate with different boundary conditions were conducted after the construction of calculation mesh, because the modes changed (namely fluid rate in the inlet of the spiral casing).

Hydraulic losses determined by the formula:

$$
\Delta h=\frac{\bar{P}_{\text {inlet }}^{\text {total }}-\bar{P}_{\text {outlet }}^{\text {total }}}{\rho \cdot g}
$$

Total losses in the inlet are presented on graph (fig. 3).

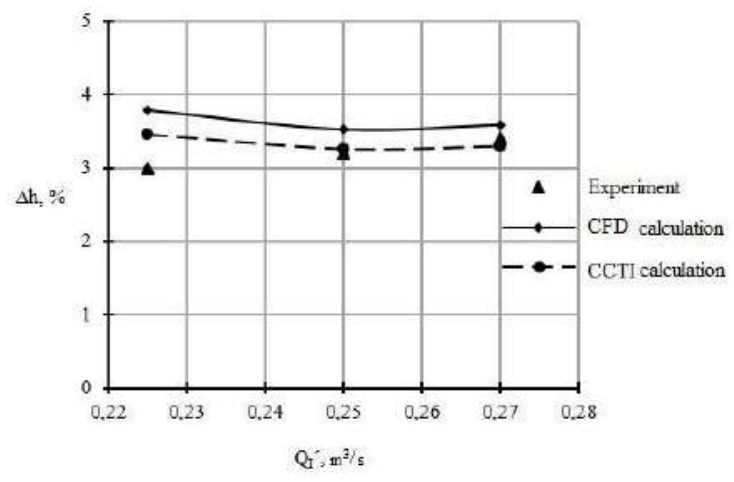

Fig. 3 - The energy losses in the inlet elements 


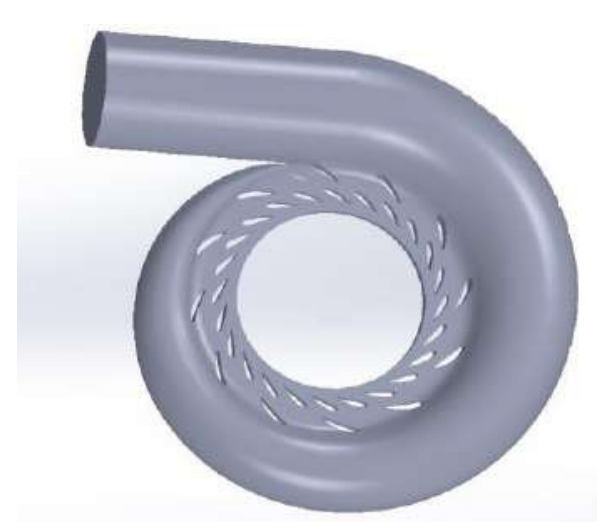

Fig. 1 - The solid model of the hydroturbine inlet

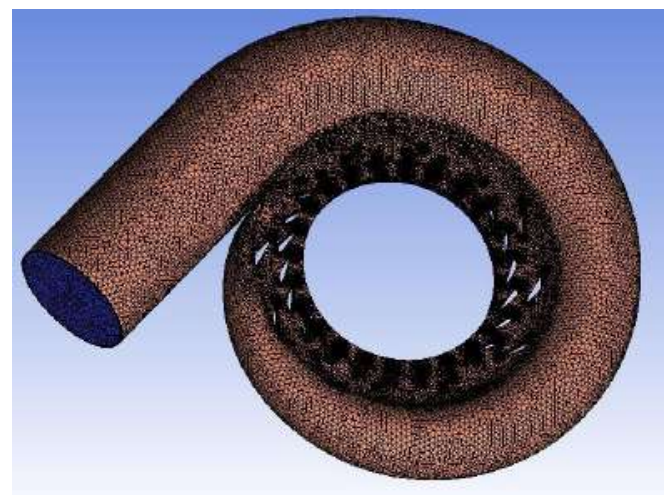

Fig. 2 - The calculation mesh

Dependences of total losses in the inlet of the hydraulic machine from the rate, which was obtained as a result of the calculation using CFD (continuous curve), CCTI (stroke curve) [5] and experiment (conformable points) are presented on a figure [4].

The calculated values of losses of total energy were confronted with data that was before determined by experiment and calculations by program CCTI.

Both the curves have identical character. formula:

The coefficients of resistances were determine by

$$
k_{h}=\frac{\bar{h} \cdot g}{\left(Q_{I}^{\prime}\right)^{2}}
$$

where $\bar{h}=\frac{\Delta h}{H}-$ relative losses.

For the optimal mode the coefficient of resistance in a spiral casing with the columns of stator is equal $k_{h s c+s t}=1.469$. The values of coefficients of resistance in inlet (spiral casing, columns of stator and wicket gate) at the different opening of wicket gate are in the table 1 .

Table 1 - Coefficient of resistance of inlet.

\begin{tabular}{|c|c|c|c|}
\hline $\mathrm{Q}_{\mathrm{I}}{ }^{\prime}, \mathrm{m}^{3} / \mathrm{s}$ & 0.225 & 0.250 & 0.270 \\
\hline $\begin{array}{c}a_{0}, \mathrm{~mm} \\
\left(\mathrm{D}_{1}=1 \mathrm{~m}\right)\end{array}$ & 48.38 & 54.44 & 60.48 \\
\hline$k_{\text {hinlet }}$ & 7.34 & 5.671 & 4.864 \\
\hline
\end{tabular}

From data of calculation researches, it may be concluded, that the dimensionless coefficient of losses of total energy depends on opening of wicket gate. The certain value of the reduced rate corresponds to this opening. When the rate increase, the coefficient decrease, and other parameters of the modes are constant. Processes that took place in the elements of the inlet of hydraulic turbine presented below more detail and demonstrably.

Flowing around of spiral casing, stator and wicket gate is presented as distribution of total pressure for each of the considering modes (fig. 4, 5, 6).

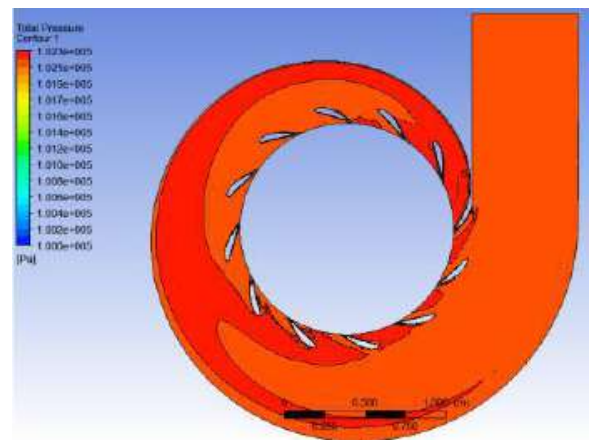

Fig. 4 -Distribution of the total pressure $\left(Q_{I^{\prime}}=0.225 \mathrm{~m}^{3} / \mathrm{s}\right.$, spiral casing with stator)

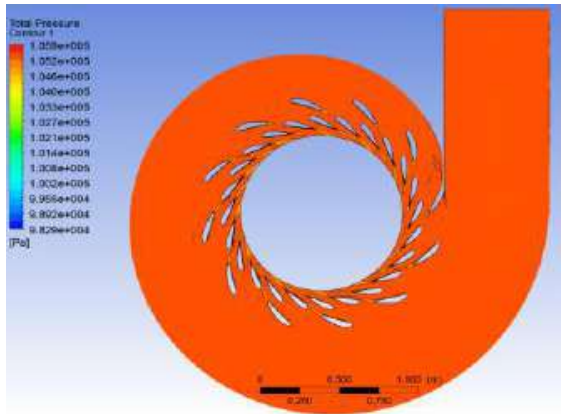

Fig. 5 - Distribution of the total pressure $\left(Q_{I^{\prime}}{ }^{\prime}=0.225 \mathrm{~m}^{3} / \mathrm{s}\right.$, spiral casing with stator and wicket gate)

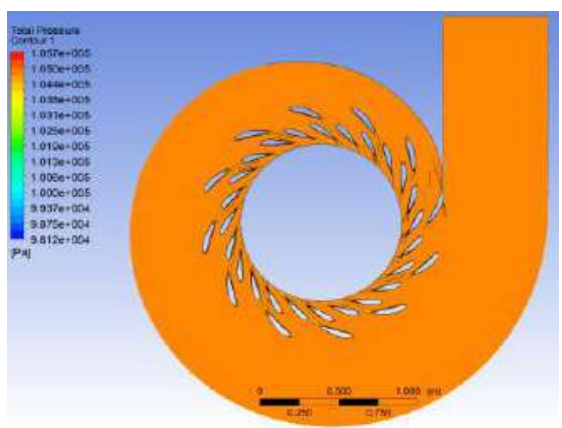

Fig. 6-Distribution of the total pressure $\left(Q_{I^{\prime}}=0.270 \mathrm{~m}^{3} / \mathrm{s}\right.$, spiral casing with stator and wicket gate)

The component of total pressure (static pressure) is represented on fig. 7, 8, 9 .

The full velocity on fig. 10, 11, 12 .

If to consider components of velocity in meridional sections (distributions of that are presented on the fig. 13), it is possible to observe a secondary flow in the spiral casing of hydroturbine. This flow leads to 
appearance of the vortex pair. The vorticity appears in a spiral casing and leads to increasing of hydraulic losses. A meridional section is considered under the angle of $\varphi=120^{\circ}$ (fig. 14).

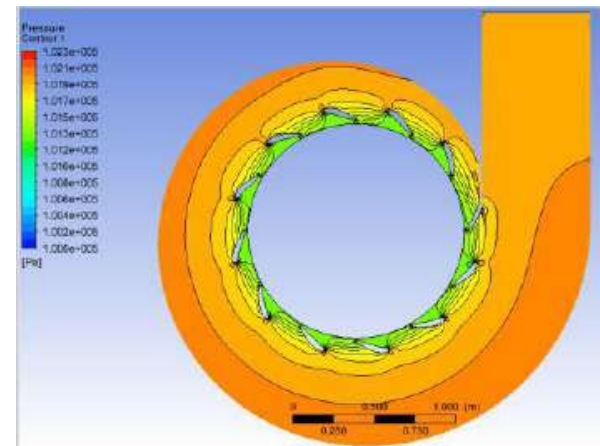

Fig. 7 -Distribution of static pressure $\left(Q_{I^{\prime}}=0.225 \mathrm{~m}^{3} / \mathrm{s}\right.$, spiral casing with stator)

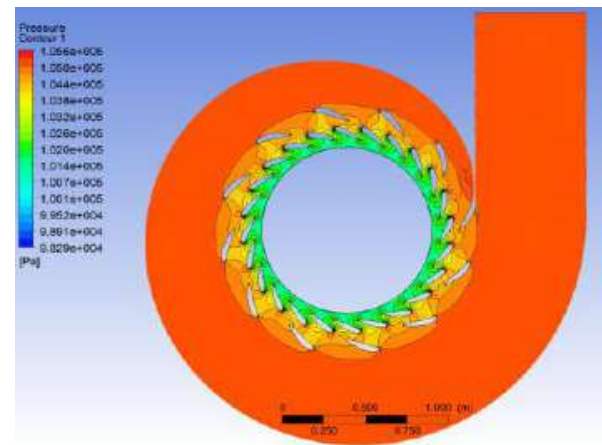

Fig. 8 -Distribution of static pressure $\left(Q_{I^{\prime}}=0.225 \mathrm{~m}^{3} / \mathrm{s}\right.$, spiral casing with stator and wicket gate)

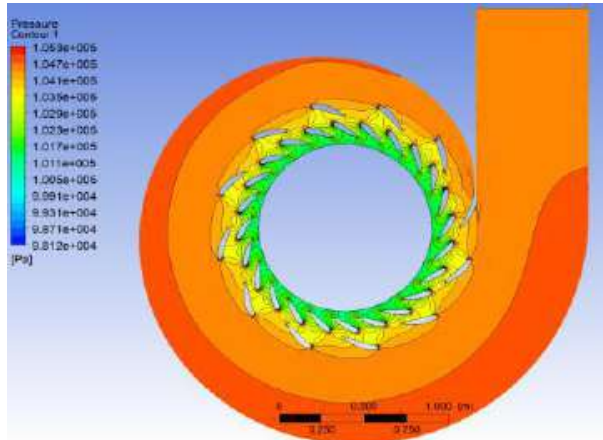

Fig. 9 - Distribution of static pressure $\left(Q_{I^{\prime}}=0.270 \mathrm{~m}^{3} / \mathrm{s}\right.$, spiral casing with stator and wicket gate)

A secondary fluid flow, which was determined in the optimal mode of operating of hydroturbine, during consideration of elements of the inlet: spiral casing with the columns of stator. This fluid flow is appeared due to complex geometry. It influences on the fluid flow in the inlet.

Appearing of the secondary fluid flow in elements of the inlet of the hydroturbine was researched not only by the program CFD but also during realization of experiment. Components of the full velocity after wicket gate were determined (before runner). The distributions of these constituents are on a height in one of meridional sections (the angle of plane of section is equal to $120^{\circ}$ ).

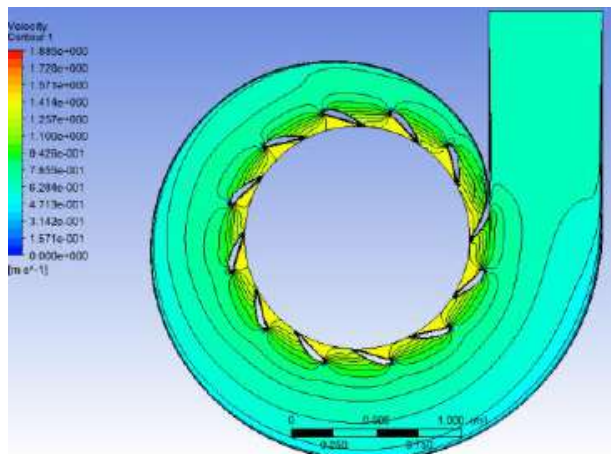

Fig. 10 - Distribution of the velocity $\left(Q_{I}{ }^{\prime}=0.225 \mathrm{~m}^{3} / \mathrm{s}\right.$, spiral casing with stator)

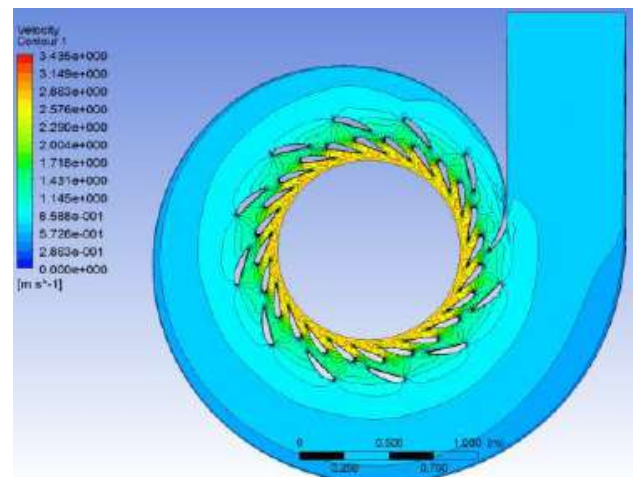

Fig. 11 - Distribution of velocity $\left(Q_{I^{\prime}}{ }^{\prime}=0.225 \mathrm{~m}^{3} / \mathrm{s}\right.$, spiral casing with stator and wicket gate)

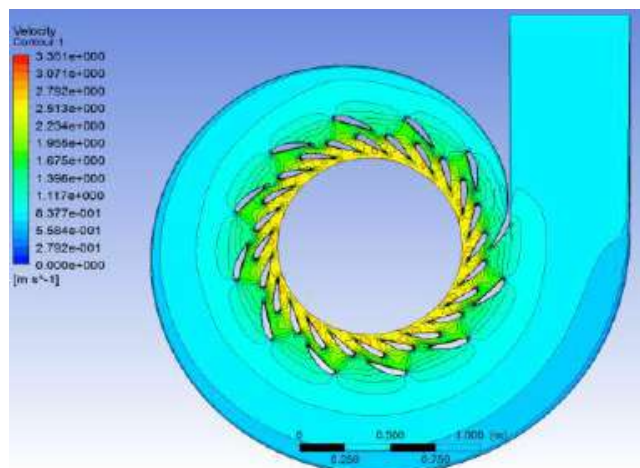

Fig. 12 - Distribution of velocity $\left(Q_{I^{\prime}}=0.270 \mathrm{~m}^{3} / \mathrm{s}\right.$, spiral casing with stator and wicket gate)

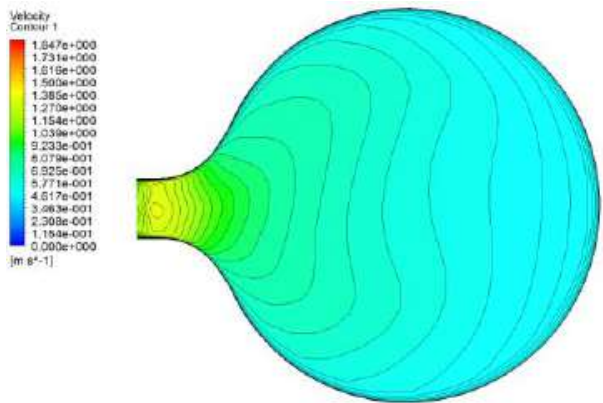

Fig. 13 -Distribution of the full velocity in the meridional section 


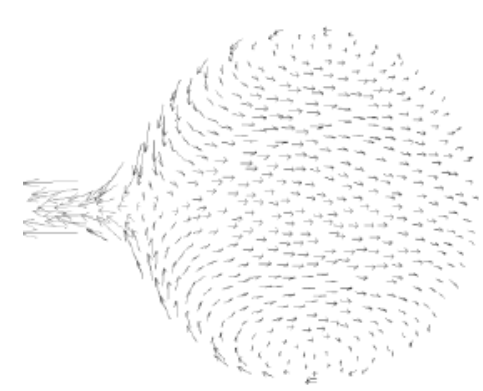

Fig. 14 - Vortex structure of the fluid flow in a spiral casing in the optimal condition

\section{Conclusions}

The experimental data and data, which were got by the calculation in the packages of specific programs, showed that losses in the inlet of hydraulic turbine are connected with the complex structure of the fluid flow. Therefore the optimal concordance of all elements of the inlet influence very much for providing of energy characteristics of hydraulic machines. During comparison of data there is a small value of errors in parameters, namely in losses. Then it is possible to say that using the packages of specific programs for prognostication of necessary results, considerably simplifies a planning process hydraulic machines.

\section{Список літератури}

1. Селезнев, В. Н. Исследование баланса потерь на основе расчета трехмерного течения вязкой жидкости в проточной части обратимой гидромашины / В. Н. Селезнев, Г. И. Топаж // Гидротехническое строительство. - Москва : Научно-техническая фирма "Энергопрогресс", 2014. - № 11. - с. 59-62.

2. Drankovsky, V. E. Calculating three-dimensional fluid flow in the spiral casing of the reversible hydraulic machine in turbine mode / V. E. Drankovsky, K. S. Rezvaya, E. S. Krupa // Bulletin of NTU "KhPI". Series: Hydraulic machines and hydrounits. - Kharkiv : NTU "KhPI", 2016. № 20 (1192). - p. 53-57.

3. Сухоребрый, П. Н. Оптимизация подвода радиальноосевых высоконапорных гидротурбин на основе численного исследования кинематических характеристик и потерь энергии / П. Н. Сухоребрый, Л. Л. Меньшикова, В. В. Барлит, В. Э. Дранковский, Е. М. Эскрибано // Пробл. машиностроения. - 2003. - Т. 2. - c. 590-594.

4. Потетенко, О. В. Вихревой характер движения жидкости в спиральной камере и межлопастных каналах направляющего аппарата высоконапорных радиальноосевых гидротурбин $\mathrm{PO} 500$ / О. В. Потетенко, Н. С. Панченко // Гидравлические машины. - 1973. - Вып.7. C. 3-9.

5. Барлит, В. В. Разработка и численное исследование подвода высоконапорной гидротурбины PO500 / В. В. Барлит, В. Э. Дранковский, Л. Л. Меньшикова, К. А. Миронов, В. К. Панде, М. К. Малу, Л. К. Харвани, С. Рао // Міжнародна наукова конферениія МіскоСAD : Секиія №5 - Моделювання робочих прочесів в теплотехнологічному, енергетичному обладнанні та проблеми енергозбереження. - Харьков : НТУ "ХПИ", 2003.
6. Потетенко, О. В. Комплексные экспериментальные исследования турбулентной структуры потока в проточной части высоконапорной радиально-осевой гидротурбины / О. В. Потетенко, Е. С. Крупа // Вісник НТУ «ХПІ». Серія: Гідравлічні машини та гідроагрегати. - Харків : НТУ «ХПІ», 2016. - № 20 (1192). - C. 33-40.

7. Ruprecht, A. Unsteady Flow Simulation in Hydraulic Machinery / A. Ruprecht // Task Quarterly. - 2002. - Vol. 6, no 1. - P. 187-208.

8. Minkowycz, W. J. Handbook of Numerical Heat Transfer. / W. J. Minkowycz, E. M. Sparrow, J. Y. Murthy- [2 ed.] - Wiley, 2006.- 984 c.

9. Jun-hu, Y. Numerical Simulation of Whole Flow Passage for a Multi-stage Hydraulic Turbine with Gas-liquid TwoPhase / Jun-hu YANG, Ting XU, Hao-ran LIU // Media Journal of Xihua University(Natural Science Edition). 2014. - Vol. 5. - P. 103-108.

10. Pasquale, D. Shape Optimization of an Organic Rankine Cycle Radial Turbine Nozzle / D. Pasquale, A. Ghidoni, S. Rebay // Journal of Engineering for Gas Turbines and Power. - 2013. - Vol. 135 (4). - P. GTP-12-1061. doi : $10.1115 / 1.4023118$.

11. Jacob, P. A. Preliminary design and performance estimation of radial inflow turbines: an automated approach / P. A. Jacob, Carlos Ventura, Andrew S. Rowlands [et al.] // Trans. ASME, Journal of Fluids Engineering. - 2012. - Vol. 134. - P. 031102-1-031102-13. doi : 10.1115/1.4006174

12. Reinmoller, U. Clocking Effects in a 1.5 - Stage Axial Turbine Steady and Unsteady Experimental Investigations Supported by Numerical Simulations [Text] / U. Reinmoller and R. Niehuis // ASME J. Turbomachines. - 2002. - 124. P. 52-58.

\section{Bibliography (transliterated)}

1. Seleznev, V. N., Topazh, G. I. Study of the balance of losses based on the calculation of the three-dimensional flow of a viscous fluid in the flowing part of a reversible hydraulic machine Hydrotechnical Construction. - Moscow: Scientific and technical firm "Energoprogress", 2014. - № 11. - p. 59-62.

2. Drankovsky, V. E., Rezvaya, K. S., Krupa, E. S. Calculating the three-dimensional fluid flow in the spiral casing of the reversible hydraulic machine in turbine mode Bulletin of NTU "KhPI". Series: Hydraulic machines and hydrounits. - Kharkiv: NTU "KhPI", 2016. № 20 (1192). p. $53-57$

3. Suhorebryi, P. N., Menshikova, L. L., Barlit, V. V., Drankovsky, V. E., Escribano, E. M. Optimization of the approach of radial-axial high-head hydroturbines on the basic of a numerical study of kinematic characteristics and energy losses. Probl. Mashinostroeniya. 2003. 2. p. 590-594

4. Potetenko, O. V., Panchenko, N. S. Vortex character of fluid motion in a spiral chamber and intervane channels of a directing device of high-thrust radial-axial hydro turbines Fr500 Hydraulic machines. 1973. 7. - P. 3-9.

5. Barlit, V. V., Drankovsky, V. E., Menshikova, L. L., Mironov, K. A., Pande, V. K., Malu, M. K., Harvani, L. K., Rao, S. Development and numerical study of the supply of the high-head hydro turbine Fr500. International scientific conference MicroCAD: Section number 5 - Models of robotic processes in heat and power engineering, energyintensive and energy-saving problems. - Kharkov: NTU "KhPI", 2003. 
6. Potetenko, O. V., Krupa, E. S. Complex experimental researches of the turbulent flow structure in the water passage of a high-head radial-axial Bulletin of NTU "KhPI". Series: Hydraulic machines and hydraulic units - Kharkov: $N T U$ "KhPI", 2016. № 20 (1192). P. 33-40.

7. Ruprecht, A. Unsteady Flow Simulation in Hydraulic Machinery. Task Quarterly. 2002. Vol. 6, no 1. P. 187-208

8. Minkowycz, W. J. Handbook of Numerical Heat Transfer. - [2 ed.] - Wiley, 2006.- 984 c.

9. Jun-hu, Y., Ting, X., Hao-ran, L. Numerical Simulation of Whole Flow Passage for a Multi-stage Hydraulic Turbine with Gas-liquid Two-Phase. Media Journal of Xihua University (Natural Science Edition), 2014. Vol. 5. P. 103108.
10. Pasquale, D., Ghidoni, A., Rebay, S. Shape Optimization of an Organic Rankine Cycle Radial Turbine Nozzle. Journal of Engineering for Gas Turbines and Power. 2013. Vol. 135 (4). P. GTP-12-1061. doi : 10.1115/1.4023118.

11. Jacob, P. A., Ventura, C., Rowlands, A. S. [et al.] Preliminary design and performance estimation of radial inflow turbines: an automated approach. Trans. ASME, Journal of Fluids Engineering. 2012. Vol. 134. P. 031102 1-031102-13. doi : $10.1115 / 1.4006174$

12. Reinmoller, U., Niehuis, R. Clocking Effects in a 1.5 Stage Axial Turbine Steady and Unsteady Experimental Investigations Supported by Numerical Simulations [Text]. ASME J. Turbomachines. 2002. 124. P. 52-58.

\section{Сведения об авторах (About authors)}

Kseniya Sergeevna Rezvaya - graduate student, Assistant of the department "Hydraulic machines" of National Technical University "Kharkiv Polytechnic Institute", Kharkiv, Ukraine; e-mail: rezvayaks@ gmail.com.

Рєзва Ксенія Серхіївна - аспірант, асистент кафедри «Гідравлічні машини» Національного технічного університету «Харківського політехнічного інституту», Харків, Україна; e-mail: rezvayaks@ gmail.com.

Evgeniy Sergeevich Krupa - Candidate of Technical Sciences (Ph. D.), Docent of the department "Hydraulic machines" of National Technical University "Kharkiv Polytechnic Institute", Kharkov, Ukraine; e-mail: zhekr@mail.ru.

Крупа Свzеній Серzійович - кандидат технічних наук, доцент кафедри «Гідравлічні машини» Національного технічного університету «Харківського політехнічного інституту», Харків, Україна; e-mail: zhekr@mail.ru.

Viktor Eduardovich Drankovskiy - Candidate of Technical Sciences (Ph. D.), Docent, Professor of the department "Hydraulic machines" of National Technical University "Kharkiv Polytechnic Institute", Kharkiv, Ukraine; e-mail: drankovskiy@ rambler.ru.

Дранковський Віктор Едуардович - кандидат технічних наук, доцент, професор кафедри «Гідравлічні машини» Національного технічного університету «Харківського політехнічного інституту», Харків, Україна; е-таil: drankovskiy@ rambler.ru.

Oleg Vasilyevich Potetenko - Candidate of Technical Sciences (Ph. D.), Docent, Professor of the department "Hydraulic machines" of National Technical University "Kharkiv Polytechnic Institute", Kharkiv, Ukraine; gmntukhpi@ gmail.com.

Потетенко Олег Васильович - кандидат технічних наук, доцент, професор кафедри «Гідравлічні машини» Національного технічного університету «Харківського політехнічного інституту», Харків, Україна; е-таil: gmntukhpi@gmail.com.

Irina Ivanovna Tynyanova - Candidate of Technical Sciences (Ph. D.), Docent of the department "Hydraulic machines" of National Technical University "Kharkiv Polytechnic Institute", Kharkov, Ukraine; e-mail: t.irinai@mail.ru.

Тиньянова Ірина Іванівна - кандидат технічних наук, доцент кафедри «Гідравлічні машини» Національного технічного університету «Харківського політехнічного інституту», Харків, Україна; e-mail: t.irinai@ mail.ru.

Please cite this article as:

Rezvaya, K., Krupa, E., Drankovskiy, V., Potetenko, O. V., Tynyanova, I. The numerical research of the flow in the inlet of the high-head hydraulic turbine. Bulletin of NTU "KhPI". Series: New solutions in modern technologies. - Kharkiv: NTU "KhPI", 2017, 7 (1229), 97-102, doi:10.20998/2413-4295.2017.07.13.

Будь ласка, посилайтесь на ичю статтю наступним чином:

Рєзва, К. С. Чисельне дослідження потоку у підводі високонапірної гудротурбіни / К. С. Рєзва, С. С. Крупа, В. Е. Дранковський, О. В. Потетенко, І.І. Тиньянова // Вісник НТУ «ХПI», Серія: Нові рішення в сучасних технологіях. Харків: НТУ «ХПІ». - 2017. - № 7 (1229). - С. 97-102. - doi:10.20998/2413-4295.2017.07.13.

Пожалуйста, ссылайтесь на эту статью следующим образом.

Резвая, К. С. Численное исследование потока в подводе высоконапорной гидротурбине / К. С. Резвая, Е. С. Крупа, В. Э. Дранковский, О. В. Потетенко, И. И. Тыньянова // Вестник НТУ «ХПИ», Серия: Новые решения в современных технологиях. - Харьков: НТУ «ХПИ». - 2017. - № 7 (1229). - С. 97-102. - doi:10.20998/2413-4295.2017.07.13.

АННотАЦИЯ Представлены результаты численного исследования трехмерного течения потока жидкости в высоконапорной радиально-осевой гидравлической турбине. Определены потери полной энергии в подводящих элементах проточной части с помощью разных пакетов прикладных программ. Произведено сравнение данные, полученных при расчетах и экспериментальных стендовых данных. Описан сложный характер течения потока жидкости. Расчетом подтверждено существования вторичного течение жидкости в спиральной камере гидравлической турбины.

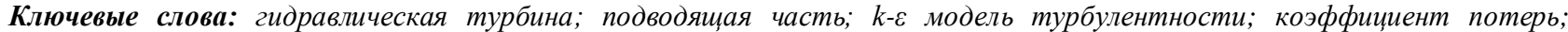
распределения давления; распределение скорости; вторичное движение 